\title{
Representations of Trust to Public Service in Russian Newspapers during Election Time: Corpus-based Content Analysis in Public Administration Sociology
}

\author{
Mariia Rubtcova ${ }^{1}$ \\ Oleg Pavenkov² \\ Vladimir Pavenkov ${ }^{3}$ \\ Elena Vasilieva ${ }^{4}$ \\ ${ }^{1}$ Associate Professor, Sociology Department, Saint Petersburg State University, Russia \\ Email: m.rubtsova@spbu.ru \\ ${ }^{2}$ Senior lecturer, St.Petersburg State University of Film and Television, Russia \\ Email: oleg.pavenkov@gmail.com \\ ${ }^{3}$ Associate Professor, St.Petersburg State University of Film and Television, Russia \\ Email: pavenkovvg@yandex.ru \\ ${ }^{4}$ Leading researcher, Academy of science of Republic of Sakha (Yakutia), Russia \\ Doi:10.5901/mjss.2015.v6n4s1p436 \\ Email: vasilievaea@asrs.ysn.ru

\section{Abstract} \\ This article presents a study of the trust as social and public administration categories from the sociological and corpus-based \\ perspective. To study the trust as the social category was elected a newspaper corpus (corpus of contemporary media). The \\ corpus includes the texts of the seven media: printed Newspapers ("Novosty", "Sovetsky sport", "Trud", "Komsomolskaya \\ Pravda"), and electronic agencies (RIA Novosti, RBC, "New region") in approximately equal volume. The study has revealed \\ that the category 'trust' in the Russian newspapers is used in the context of political institutions. The political context means \\ that the text describes the relationship of the actors of public administration, who, in Russia, often are the staff of public service. \\ We believe that this fact highlights the loyalty of people to the authorities. It is indirectly confirmed by the data of positive \\ mentions of trust in the context of 'respect' and 'authority'. In 2011, State Duma elections took place, with the number of \\ mention of trust in political institutional context decreasing more than twice. Thus, in the pre-election period, the significance of \\ the problem of recognition and respect for the subjects of political institutions in the media decreases, but increases the \\ importance of social harmony.
}

Keywords: conceptualisation, corpus-based content analysis, public administration sociology, public service, trust

\section{Introduction}

This article presents a study of the trust as social and public administration categories from the sociological and corpusbased perspective, and includes a small-scale study that analyses the way in which this concept is used in Russian. The trust has been a subject of scientific interest for more than half of century. A sociological approach to the study of trust is multifaceted. In a classic sociological work (Durkheim,1960; Weber,1997; Parsons, 1978 \& Sztompka, 1999), trust is defined as a phenomenon providing social consensus and order, and the unity of society in the face of external risks. Garfinkel (1963) considers trust a necessary background condition of any mutually intelligible interaction, and states that trust requires the mutual approval of the norms and rules regularising public life (Watson, 2009). In this vein, Luhmann (1979) distinguishes this concept as a relation of dependence, which could lead to risk, social activity and the situation of choice. Comparably, economists emphasise that trust is a prerequisite for the activity in the risk situation, describing it as 'a mechanism that can reduce uncertainty in contexts of interaction and facilitate the functioning of organizational systems' (Malsch \& Gendron, 2009). As Watson (2009) established, in modern social research, there are two main technologies of the operationalisation of trust, namely as terms of something else (choice, risk, game etc.) or as habitus (function).

Leith (2013) identifies three theoretical approaches to trust: an expectation, which the individual assimilates in childhood and uses to deal with the situation of uncertainty and risk; a community's capacity to take collective action in order to resolve common social issues or problems; and the mark of truth-telling, where trust is the foundation of 
relationships. Importantly, Fuglsang (2015) describes the institutional-based approach to trust (Fuglsang \& Jagd, 2015) in terms of relations between organisations and individuals. He stresses that the trust is based on sense-making of institutional elements by actors, and in the terms of changing environmental conditions, the actors have to consider the meanings accepted in new society. Thus, the sociological definition of trust is based on its role in society as the foundation of social cohesion and harmony: if actors have the same notions, they cling together in terms of risk and choice. Seligman (2000), in 'The problem of Trust', treats trust as a social resource renewable.

Public service is one of the main institutions of ensuring civil concord in society. In the Russian tradition, this relates to the staff of executive authorities (Atamanchuk, 2008; Obolonsky, 2011; Barabashev \& Straussman, 2007), who are required to execute the function of state, including defence, policing and law-making. The same definition is typical for China: the civil service is the actor of governance (Chan \& Suizhou, 2007; Wu, 2014). In the liberal tradition, public service has no political function. In the frames of New Public Management (NPM), this institution deals with only the system of public goods delivery. The main portion of researchers is focused on the results of administrative reforms in different countries and in different terms, who analyse the problems pertaining to the efficiency of the system of public goods (Banerjee \& Hankla, 2014; Kumar, 2014; Puron-Cid, 2014; Knox, 2008; Héritier, 2001) in regard to the concept of 'good government' or 'performance management' as the next range of reform (West \& Blackman, 2015; Amirullah, 2014) or of the professionalising of civil service during the reform (Gellén, 2013; O'Flynn, Vardon, Yeatman \& Carson, 2011). In this discourses, it was established that public service requires further transparency and strengthening cooperation with civil society. In 2013, McCourt clearly showed that there is no universal form of administrative reforms, which are successful in any country (McCourt, 2013).

Considerable attention also has been directed to the study of trust in the political system-especially in extremal situations, such as in terrorist attacks (Gross, Brewer \& Aday, 2009) or revolutions (Carlin, 2011) or in the virtual environment (Zornoza, Orengo \& Peñarroja, 2009); trust has been identified as the important phenomenon, forming the relations between state and civil society. If political institutions, such as parties and government, inspire confidence, the negative impact of social tension and economic crises could be mitigated. However, if the political system was to be distrusted, there then would be a rise in the threat of totalitarianism or a big social shock. Importantly, generalised trust is one of the components of social capital (Kääriäinen \& Sirén, 2011), and is known to promote to the social cohesion and activates the potential of civil society. The influence of newspapers and other mass-media is the subject of much empirical research, including content analysis and panel studies (Avery, 2009; Kleinnijenhuis, van Hoof \& Oegema, 2006; Ceron \& Memoli, 2015). It has been recognised that the influence of mass media in and across the political system depends on conditions of society. There are no relations between the forms of mass media and their influence; this only depends on the attitude of the population to the media: for example, if people trust newspapers or internet sites, the information is considered significant. The media acts as 'echo-chambers': they do not form the negative/positive relationships to the government, but rather fix and retransmit it to their audience.

Public Opinion Research Centres accumulate a wealth of empirical data on trust in public administration; however, modern methods of analysis do not allow the influence of public trust to the efficiency of governance to be assessed. The methods of sociolinguistic could combine qualitative and quantitative methodology. The School of Linguistic Pragmatics has a significant progress in this sphere (Halliday \& Hasan, 1976; McCabe, O'Donnell \& Whittaker, 2007; Romero-Trillo, 2011; Romero-Trillo \& Cheshire, 2014; Gladkova \& Romero-Trillo, 2014), and has created a special software (Corpus Tool). The authors seek to account for the nuances of verbal and journalistic speech, including irony and hidden meanings. Caldas-Coulthard and Moon are stated that 'corpus studies can help to deconstruct hidden meanings and the asymmetrical ways people are represented in the press' (Caldas-Coulthard \& Moon, 2010: 99).

However, linguistic science pays little attention to the social context from a sociological point of view, reducing it to the context of the speech act 'here and now'. This requires adjustments to the linguistic techniques for the purposes of sociological and sociolinguistic research. The use of sociolinguistic methods in assessing the level of trust in media will help eliminate the subjectivity of the classical sociological methods of measuring the level of confidence in the activities of public authorities, and will also enhance the prospects of the use of methods of linguistic pragmatics.

This methodology, which will be used to analyse social concepts, has been submitted in previous papers, and is recognised as a common methodology in works such as those by Pavenkov \& Rubtcova (2015) and Vasilieva (2011), Rubtcova (2015), with application in Rubtcova, Pavenkov, Pavenkov \& Vasilieva (2015). We believe that corpus linguistics has the capacity to provide management sociology with a necessary analytical tool, allowing us to identify potential problems in the use and interpretation of key research concepts. The study of the concept should include the study of synonyms when considering the wide-ranging implementation of such by sociologists and respondents.

Using our approach, based on the Russian National Corpus (2015), we can establish similarities and differences in the use of the word «trust» and accordingly seek to find answers to our research questions: 
What is the distribution of mention of the category 'trust' in institutional and lexical contexts?

How is trust to public service represented in Russian newspapers?

Has this representation changed in the period of election?

To this aim, the following hypotheses can be devised and verified:

Hypothesis 1: The use of word «trust» in institutional and lexical contexts has statistically significant differences.

Hypothesis 2: The trust to public service is represented in Russian newspapers as mostly positive.

Hypothesis 3: During the election period, the mention of 'trust' in the political institutional context has changed.

\section{Method}

\subsection{Design}

The proposed research methodology adopts a combination of quantitative and qualitative analysis of the coded array of National corpus of the Russian language, developed by specialists in corpus linguistics and representing modern Russian language in all its diversity. This includes texts of different types, in accordance with their shares during the specified period, providing representativeness. Quantifying the frequencies of word used was based on experts' context encoding, performed by three independent experts, who represented the St. Petersburg state University, North-Eastern Federal University, named after M. Ammosov, and the Academy of Sciences of the Republic of Sakha (Yakutia).

The coding was carried out across two stages: in the first stage, the theme of the whole text was defined in the institutional context; in the second stage, the lexical context was analysed, allowing a specific value of the category to be defined in an institutional context and estimates context, allowing the emotional background of the used categories to be taken into account.

\subsection{Sampling Procedures}

Studying trust as a social category, a newspaper corpus (corpus of contemporary media) was selected as it most adequately reflects the trends of the modern Russian language. The corpus includes the texts of the seven media: printed Newspapers ('Novosty', 'Sovetsky Sport', 'Trud', 'Komsomolskaya Pravda'), and electronic agencies (RIA Novosti, RBC, 'New Region') in approximately equal volume. It contains 181,175 texts, which allows 8,553,495 sentences to be analysed (see Table 1). The analysis was carried out for the period spanning May 2010-May 2011. During this period, the category of 'trust' in the media was used 1,261 times, including 835 times in 2010 and 426 times in 2011. Corpus Tool 3.1.14 processed the data in an effort to identify a structure of the analysis of this social category. The established structure has allowed the processing of data in SPSS to be implemented.

Table 1. The distribution of the concepts 'trust' in the Russian National Corpus

\begin{tabular}{clll}
\hline & \multicolumn{3}{c}{ Corpus } \\
\cline { 2 - 4 } & Main & Newspaper & Spoken \\
\hline \multirow{2}{*}{ Total documents, sentences and words in Corpus } & 85996 documents, & 332720 documents, & 3525 documents, \\
& 19362746 sentences, & 12920590 sentences, & 1623625 sentences, \\
& 229968798 words & 173518798 words & 10754403 words \\
\multirow{2}{*}{ Word 'trust' in the Corpus, including wordforms } & 3843 documents, & 7730 documents, & 200 documents, \\
& 9191 words & 9900 words & 394 words \\
\hline \multicolumn{7}{c}{ Including the distribution for years: } \\
\hline \multicolumn{5}{c}{36} & 473 & - \\
\hline
\end{tabular}

\section{Results}

Experts offered the tree of contexts, submitted in Appendix 1. The category 'trust' is mentioned in the following institutional contexts:

Economic Institutions: The texts describing the relationship of actors in production, distribution, exchange and the consumption of material goods;

Political Institutions: The texts describing the relationship of the actors of public administration, including civil society institutions within the state and on the international (global) level. 
Social Network: The texts describing interpersonal relationships, and the interaction of various social groups.

Legal Institutions: The texts describing the interaction in the framework of law and internal security, including messages describing the crime.

Organisation: The texts describing the activities of companies and institutions, including legitimised public associations.

In the lexical context, the following values of the use categories of trust were highlighted:

Psychological Support: Organisation, which can provide psychological support on the condition of anonymity. Stable expression describes the value as: 'helpline', 'trust service'.

Message: A process of filing a complaint or reporting violations, which allows proposals to be submitted for improvement of the performance of officials on the condition of anonymity. Stable expression: 'You can make a complaint by telephone of trust'.

Approval: The acceptance of solutions previously adopted by the actor without change, and permission to continue activities. The expression 'received a credit of trust', 'vote of confidence'.

Acceptance: The adoption of the subject as a full-fledged participant in the interaction. Expressions include 'credibility', 'trust mark', 'to win the trust', 'demonstrates the trust of others' and 'unworthy of trust'.

Interaction: The willingness of the subjects of relationships to take into account mutual interests. Expressions include 'confidence building measure', 'communication builds trust' and 'mutual trust'.

Expectations: Willingness to accept the affirmation as true. The expression 'to win the trust of customers', 'trust index' and 'consumer trust'.

Respect: The informal high assessment of personal qualities or activities of the person, independent of his official status. The expression 'degree of confidence in the parents', 'everything must build on trust and loyalty' and 'I feel the trust and support'.

Authority: The ability of the person to make a power impact, based on his outstanding personal qualities and social status. Expressions include 'trust in government', 'the credibility of the President' and 'trust rating of the party'.

Deception: An unfounded belief of the owner of the property in the good faith intentions of the person. Expressions include 'the damage by deception or abuse of trust', 'easily come in the trust' and 'to elbow into confidence'.

In the framework of the current study, the estimates context was represented through two dimensions, namely positive and negative, where trust is an extra emotionally social category, which does not imply neutral evaluations.

The studying of the word 'trust', according to this context tree, led to the results discussed below.

Most of the mentions of categories in which 'trust' occurs are seen in the context of political institutions (451 mentions, equating to $35.8 \%$ ) and social network (404 mentions, equating to $32 \%$ ). In the lexical context, most often, trust is mentioned in the context of acceptance (432 mentions, equating to $34.3 \%$ ) and authority (247 mentions, equating to 19.6\%) (see Table 2).

Table 2. The distribution of mention of the category "trust" on institutional and lexical contexts

\begin{tabular}{lcccccccccccc}
\hline & \multicolumn{1}{c}{ Organization } & Political institution & \multicolumn{1}{c}{ Economical institution } & \multicolumn{1}{c}{ Social network Legal institution } & \multicolumn{2}{c}{ Total } \\
\cline { 2 - 16 } & Кол & $\%$ & Кол & $\%$ & Кол & $\%$ & Кол & $\%$ & Кол & $\%$ & Кол & $\%$ \\
\hline Psychological support & 50 & 60,2 & 0 & - & 0 & - & 0 & - & 0 & - & 50 & 4,0 \\
Message & 21 & 25,3 & 0 & - & 0 & - & 0 & - & 48 & 44,9 & 69 & 5,5 \\
Approval & 1 & 1,2 & 97 & 21,5 & 10 & 4,6 & 68 & 16,8 & 0 & - & 176 & 14,0 \\
Acceptance & 10 & 12,0 & 127 & 28,2 & 147 & 68,1 & 142 & 35,1 & 6 & 5,6 & 432 & 34,3 \\
Interaction & 0 & - & 74 & 16,4 & 0 & - & 3 & 0,7 & 0 & - & 77 & 6,1 \\
Expectation & 0 & - & 0 & - & 44 & 20,4 & 0 & - & 0 & - & 44 & 3,5 \\
Respect & 1 & 1,2 & 19 & 4,2 & 10 & 4,6 & 88 & 21,8 & 0 & - & 118 & 9,4 \\
Authority & 0 & - & 134 & 29,7 & 5 & 2,3 & 103 & 25,5 & 5 & 4,7 & 247 & 19,6 \\
Deception & 0 & - & 0 & - & 0 & - & 0 & - & 48 & 44,9 & 48 & 3,8 \\
Total & 83 & 100 & 451 & 100 & 216 & 100 & 404 & 100 & 107 & 100 & 1261 & 100 \\
\hline
\end{tabular}

In the estimates context, the category 'trust' has been positively mentioned more frequently, although the differences between positive and negative mentions are insignificant (see Table 3). The predominance of negative statements is 
identified only in the context of a legal institution, which is associated with the definition of trust as an indication of manipulative influence. In the lexical context, the negative connotations are more often associated with the definition of trust as deception, expectations and authority (see Table 4).

Table 3. The distribution of mention of the category "trust" on institutional and evaluation contexts

\begin{tabular}{lccccccc}
\hline & & Organization & Political institution & Economical institution & Social network & Legal institution & Total \\
\hline \multirow{2}{*}{ Positive } & 54 & 249 & 125 & 233 & 34 & 695 \\
& $\%$ & 65,1 & 55,2 & 57,9 & 57,7 & 31,8 & 55,1 \\
\multirow{4}{*}{ Negative } & 29 & 202 & 91 & 171 & 73 & 566 \\
& $\%$ & 34,9 & 44,8 & 42,1 & 42,3 & 68,2 & 44,9 \\
\multirow{2}{*}{ Total } & & 83 & 451 & 216 & 404 & 107 & 1261 \\
& $\%$ & 100,0 & 100,0 & 100,0 & 100,0 & 100,0 & 100,0 \\
\hline
\end{tabular}

Table 4. The distribution of mention of the category "trust" on lexical and evaluation contexts

\begin{tabular}{ccccccc}
\hline & \multicolumn{2}{c}{ Positive } & \multicolumn{2}{c}{ Negative } & \multicolumn{2}{c}{ Total } \\
\cline { 2 - 7 } & Count & $\%$ & Count & $\%$ & Count & $\%$ \\
\hline Psychological support & 33 & 66,0 & 17 & 34,0 & 50 & 100 \\
Message & 44 & 63,8 & 25 & 36,2 & 69 & 100 \\
Approval & 122 & 69,3 & 54 & 30,7 & 176 & 100 \\
Acceptance & 218 & 50,5 & 214 & 49,5 & 432 & 100 \\
Interaction & 64 & 83,1 & 13 & 16,9 & 77 & 100 \\
Expectation & 16 & 36,4 & 28 & 63,6 & 44 & 100 \\
Respect & 85 & 72,0 & 33 & 28,0 & 118 & 100 \\
Authority & 112 & 45,3 & 135 & 54,7 & 247 & 100 \\
Deception & 1 & 2,1 & 47 & 97,9 & 48 & 100 \\
Total & 695 & 55,1 & 566 & 44,9 & 1261 & 100 \\
\hline
\end{tabular}

In 2010, trust was mentioned 835 times, whilst in 2011 was mentioned 426 times, with the most significant decrease noted in the context of political institutions and social network (see Figure 4).

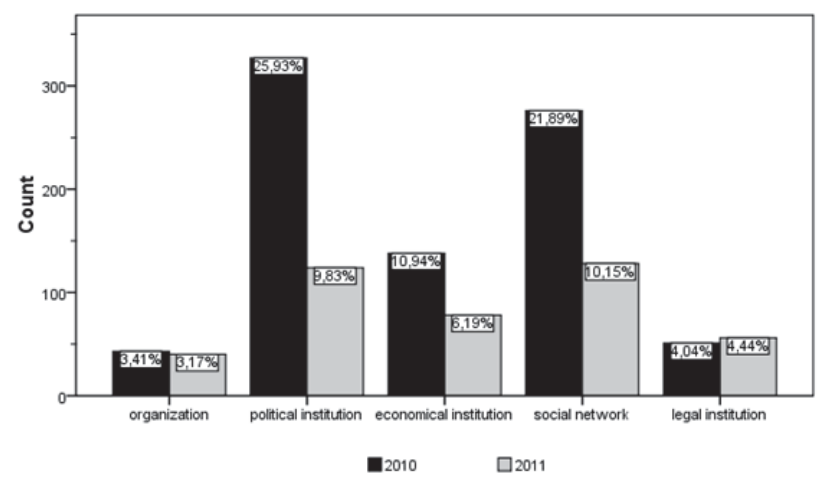

Figure 4. The distribution of mention of the category "trust" on institutional contexts

Given that, in 2011, the elections of deputies of the State Duma of the Federal Assembly of the Russian Federation of the sixth convocation were held, we can assume that this change can be associated with the election campaign. In the lexical context of the decline in the values of the approval, acceptance, interaction, respect and authority, i.e. belonging to the 
political institution (see Figure 5), the earlier-devised hypothesis can be confirmed.

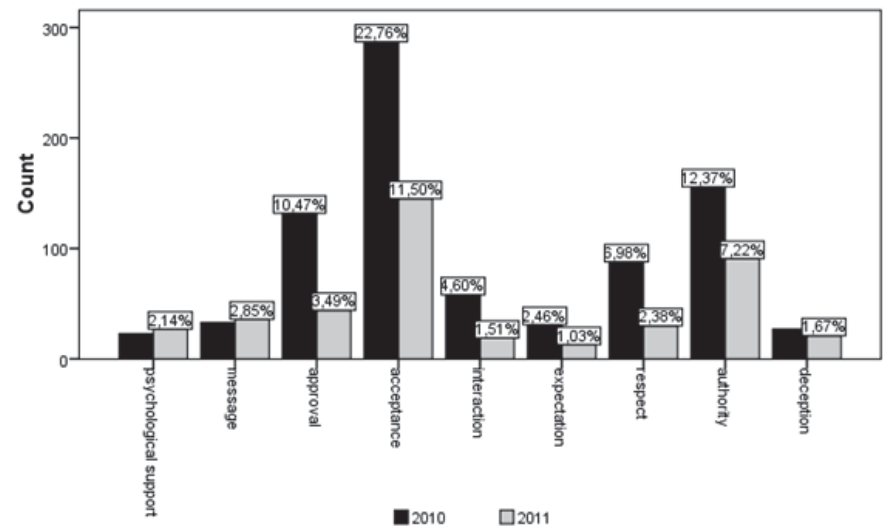

Figure 5. The distribution of mention of the category "trust" on Lexical contexts

\section{Conclusion and Discussion}

An accounting of the time frames allows the identification of the change of frequency and the semantic load of the application categories, which may indicate a change of the relevance of the study of social problems. Therefore, the study has revealed that the category 'trust' in the Russian newspapers is used in the context of political institutions. In the preelection period, the significance of the problem of recognition and respect for the subjects of political institutions in the media decreases, but increases the importance of social harmony. Thus, we can conclude that the personal qualities of political actors should be less significant in Russian society than the formal status and the willingness to make arrangements.

Hypothesis 1 is confirmed. The statistical analysis program SPSS 17.0 shows that the differences have statistical significance. The result of the procedure T-test reveal that the use of the category of 'trust' in institutional, lexical and evaluation context differs significantly $(p<0,000)$. Pearson Chi-Square confirmed the results.

Moreover, Hypothesis 2 has also been confirmed. The positive mention of trust in a political context (55.2\%) is more than negative (44.8\%). The political context means that the text describes the relationship of the actors of public administration, who, in Russia, often are the staff of public service. We believe that this fact highlights the loyalty of people to the authorities. It is indirectly confirmed by the data of positive mentions of trust in the context of 'respect' and 'authority': $72 \%$ and $45.3 \%$, respectively.

Hypothesis 3 has been confirmed. In 2011, State Duma elections took place, with the number of mention of trust in political institutional context decreasing more than twice. An earlier research (Vasilieva, 2015) shows that, in newspapers of Republic of Sakha (Yakutia), one of the subjects of Russian Federation-the number of mentions of public servicedecreased in September 2013 during the II Tumen (Yakutian State Assembly) elections. The Yacutian newspapers define public service as the administrator of socio-economic development, and are convinced that the efficiency of this institution influences the quality of life in the republic. The respondents avoid positive or negative marks, and instead prefer neutral statements. This could evidence that, in society, there is no clear view concerning the role and contribution of public service in the results of socio-economic development. We could also assume that media refrain from publishing in order to avoid violations of the law and suspicion of the use of administrative resources.

Therefore, the proposed method of Corpus linguistics helps us to identify the meanings of social categories and trends in its use in the media. A study of the institutional and lexical context allows us to define the distribution of certain values in a variety of themes, which allows us to formalise the process of social concepts' operationalisation.

\section{References}

Abulof, U. (2015). Normative concepts analysis: unpacking the language of legitimation. International Journal of Social Research Methodology, 18 (1), 73-89, http://dx.doi.org/10.1080/13645579.2013.861656

Amirullah, (2014). Public Private Partnership: A Tool in Promoting Good Governance in India. International Journal of Advanced 
Research in Management and Social Sciences, 3 (9). 102-120.

Atamanchuk, G.V. (2008). The essence of public service: the history, theory, law, practice. Moscow. RAGS publisher

Apresjan, Ju., Boguslavsky, I., Lomdin, B., Lomdin, L., Sannikov, A. \& Sizov, V. (2006). A Syntactically and Semantically Tagged Corpus of Russian: State of the Art and Prospects. Proceedings of LREC. Genova, Italy. Pp. 1378-1381.

Apresyan, Yu. D. (1988). Pragmaticheskaya informaciya dlya tolkovogo slovarya. Pragmatika i problemy intensional'nosti. Institut yazykoznaniya AN SSSR. Problemnaya gruppa "Logicheskijanaliz yazyka". Moscow.Nauka.

Archer, M. S. (2012). Reflexive Imperative in Late Modernity. Reflexive Imperative in Late Modernity, 1-340. http://dx.doi.org/10.1017/ cbo9781139108058

Avery, J. M. (2009). Videomalaise or Virtuous Circle? The Influence of the News Media on Political Trust. International Journal of Press/Politics 14 (4). 410-433.

Banerjee S. \& Hankla Ch.R. (2014). Party Systems and Public Goods: The Dynamics of Good Governance in the Indian States. Annual Convention of the American Political Science Association. Washington, DC, 31

Barabashev, A. \& Straussman J. D. (2007). Public Service Reform in Russia, 1991 - 2006. Public Administration Review, May/June 2007. 373-382

Benoit, M. (2012). Qu'est-ce que le corporatisme? Conceptualisation et opérationnalisation du méso-corporatisme. Social Science Information, 51(2), 217-237.

Blei, D. M. (2012). Probabilistic Topic Models. Communications of the Acm, 55(4), 77-84. http://dx.doi.org/10.1145/2133806.2133826

Blumczyński, P. (2013). Turning the tide: A critique of Natural Semantic Metalanguage from a translation studies perspective. Translation Studies, 6:3, 261-276.

Boym, S., (1994). Common Places: Mythologies of Everyday Life in Russia. Harvard University Press, Cambridge/London.

Caldas-Coulthard, C. R., \& R. Moon. (2010). "'Curvy, Hunky, Kinky': Using Corpora as Tools for Critical Analysis." Discourse \& Society, 21 (2): 99-133. http://dx.doi.org/10.1177/0957926509353843.

Cap, P. (2008). Towards the proximization model of the analysis of legitimization in political discourse. Journal of Pragmatics, 40(1), 1741. http://dx.doi.org/10.1016/j.pragma.2007.10.002

Carlin, R.E. (2011). Distrusting Democrats and Political Participation in New Democracies: Lessons from Chile. Political Research Quarterly. http://dx.doi.org/10.1177/1065912910370692

Ceron, A. \& Memoli, V. (2015). Trust in Government and Media Slant: A Cross-Sectional Analysis of Media Effects in Twenty-Seven European Countries. The International Journal of Press/Politics, 1-21. http://dx.doi.org/10.1177/1940161215572634

Creamer, E. G. \& Ghoston, M. (2013). Using a Mixed Methods Content Analysis to Analyze Mission Statements from Colleges of Engineering. Journal of Mixed Methods Research, 7(2), 110-120. http://dx.doi.org/10.1177/1558689812458976

Durkheim, E. (1960). The division of Labor in Society. New York,

ElderVass, D. (2012). Reality of Social Construction.

Fuglsang, L. \& Jagd, S. (2015). Making sense of institutional trust in organizations: Bridging institutional context and trust. Organization, 22(1) 23-39. http://dx.doi.org/10.1177/1350508413496577

Garfinkel, G. A. (1963). Conception of, and experiments with, "trust" as a condition of stable concerted actions. Motivation and Social Interaction: Cognitive Determinants / Harvey O.J. (Ed.). New York, Ronald

Gellén, M. (2013). Professionalization of Civil Service in Hungary: the Potential Impacts of Centralizing Public Administration Education. Mednarodna revija za javno upravo, XI(2), 93-104.

Gerhart, G. (2001). The Russian's World: Life and Language. Slavica Publishers, Bloomington.

Gladkova, A. \& Romero-Trillo, J. (2014). Ain't it beautiful? The conceptualization of beauty from an ethnopragmatic perspective. Journal of Pragmatics. 60, 140-159

Goddard, C. \& Wierzbicka A. (1995). Key words, culture and cognition. Philosophica. 55(1), 37-67.

Goertz, G. (2012). Social Science Concepts: A User's Guide: Princeton University Press

Goertz G., Mahoney J. 2012. Concepts and measurement: Ontology and epistemology. Social Science Information, 51 (2), 205-216

Grimmer, J. \& Brandon, S. M. (2013). Text as Data: The Promise and Pitfalls of Automatic Content Analysis Methods for Political Texts. Political Analysis, 21(3), 267-297. http://dx.doi.org/10.1093/pan/mps028

Gross, K., Brewer, P.R. \& Aday, S. (2009). Confidence in Government and Emotional Responses to Terrorism after September 11, 2001. American Politics Research, 37 (1), 107-128.

Halliday, M. \& Hasan, R. (1976). Cohesion in English. London: Longman.

Héritier, A. (2001). The Politics of Public Services in European Regulation. Max-Planck-Projektgruppe Recht der Gemeinschaftsgüter. Bonn 2001/1. Retrieved from: http://papers.ssrn.com/paper.taf?abstract_id=269314

Kääriäinen, J. \& Sirén, R. (2011). Trust in the police, generalized trust and reporting crime. European Journal of Criminology, 8(1), 65-81 http://dx.doi.org/10.1177/1477370810376562

Kleinnijenhuis, J., van Hoof A., \& Oegema D. (2006). Negative News and the Sleeper Effect of Distrust. The International Journal of Press/Politics, 11(2), 86-104. http://dx.doi.org/10.1177/1081180X06286417

Knox, C. (2008). Kazakhstan: modernizing government in the context of political inertia. International Review of Administrative Sciences. 74(3). 477-496.

Kumar, R. (2014). Enhancing the Reach of Public Services through Mobile Governance: The Mobile Seva Initiative in India. Retrieved from: http://ssrn.com/abstract=2575270

Leith, D. (2013). Representations of the concept of trust in the literature of Library and Information Studies. Cosmopolitan Civil Societies 
Journal, 5 (3).

Luhmann, N. (1979). Trust and power. New York. John-Wiley.

McCabe, A., O'Donnell, M. \& Whittaker, R. (Eds) (2007). Advances in Language and Education. London: Continuum.

Malsch, B \& Gendron, Y. (2009). Mythical representations of trust in auditors and the preservation of social order in the financial community. Critical Perspectives on Accounting. 20, 735-750.

Martyanov, D. S., Martyanova, N. A. \& Rubtsova, M.V. (2013). Professional and expert communities as subjects of management in the context of the knowledge society and deprofessionalization. Vestnik of St. Petersburg State University. Series 12. Psychology. Sociology. Education. [Vestnik Sankt-Peterburgskogo Universiteta. Serija 12: Psihologija. Sociologija. Pedagogika]. 1, 69-74.

Martyanova, N.A \& Rubtsova, M.V. (2012). Institutional altruism in professional practice: the sociological analysis of professions of Robert K. Merton. Vestnik of St. Petersburg State University. Series 12. Psychology. Sociology. Education. [Vestnik SanktPeterburgskogo Universiteta. Serija 12: Psihologija. Sociologija. Pedagogika]. 1, 152-158.

Martyanova, N.A. \& Rubtcova, M.V. (2015). The Identity Management Practices of Beauty-Bloggers: A Multimodal Approach to the Deprofessionalization's Analysis. Studia Humanitatis. 1, 20. http://dx.doi.org/10.2139/ssrn.2599918

McCourt, W. (2013). Models of Public Service Reform. A Problem-Solving Approach. Policy Research working paper ; no. WPS 6428. Washington, DC: World Bank. Retrieved from: http://documents.worldbank.org/curated/en/2013/04/17649169/models-publicservice-reform-problem-solving-approach

Menshikova, G.A. \& Pavenkova, M.V. (2001). The institutional matrix and the developments of Russia (Kirdina S.G.). Sociological Journal [Sociologicheskij zhurnal] 1, 140-144.

Obolonsky, A.V. (2011). Crisis of the Bureaucratic State. Moscow, Fond "Liberalnaya Missiya".

O'Flynn, J., Vardon, S., Yeatman, A. \& Carson, L. (2011). Perspectives on the Capacity of the Australian Public Service and Effective Policy Development and Implementation. The Australian Journal of Public Administration, 70 (3), 309-317.

Parsons, T. (1935). The Place of Ultimate Values in Sociological Theory. International Journal of Ethics, 45(3), 282-316.

Parsons, T. (1978). Action Theory and the Human Condition. New York: Free Press.

Pavenkov, O.V. (2010). Concept of Altruistic Love in philosophy of N.O. Lossky and Culturology Of P.A Sorokin. Vestnik Nekrasova Kostroma State University. [Vestnik Kostromskogo Gosudarstvennogo Universiteta Im. N.A. Nekrasova] 16 (2), 54-60.

Pavenkov, O.V. (2014a). Christian Ethic of Love and Hindu Ethic of Dharma: Comparative Analysis. Studia Humanitatis. $3,9$.

Pavenkov, O.V. (2014b). Contemporary Linguistic Analysis of the Concept "Love". Studia Humanitatis. 4, 8. http://dx.doi.org/ 10.2139/ssrn.2578269

Pavenkov, O.V. \& Rubtcova, M.V. (2015) The Conceptualization of Love in Religious Thought of George Florovsky and Michael Pomazansky. Studia Humanitatis. 1., 10. http://dx.doi.org/10.2139/ssrn.259991

Pavenkov, O.V., Pavenkov, V. \& Rubtcova, M.V. (2014) Linguistic Pragmatics in Advertising Research: Conceptual Framework. International scientific-practical conference "Actual problems of development of the media industry at the present stage", St. Petersburg. St. Petersburg State University of Cinema and Television. Cultural Dimensions \& Organizational Behavior eJournal, 6 (7) http://dx.doi.org/10.2139/ssrn.2573092

Puron-Cid, G. (2014). Factors for a successful adoption of budgetary transparency innovations: A questionnaire report of an open government initiative in Mexico. Government Information Quarterly 31 (2014). 49 - 62

Romero-Trillo, J. (2011). The Representation of Liminality Conflicts in the Media. Journal of Multicultural Discourses, 6 (2), $143-58$. http://dx.doi.org/10.1080/17447143.2010.545412.

Romero-Trillo, J. \& Cheshire, C. (2014). The Construction and Disarticulation of National Identities through Language Vis-À-Vis the Scottish Referendum of Independence. Lodz Papers in Pragmatics, 10 (1). http://dx.doi.org/10.1515/lpp-2014-0003

Rubtcova, M. V. (2010). The sociological theory of manageability. Sociologičeskaâ Teoriâ Upravlâemosti. Saint Petersburg, Knižnyj dom

Rubtcova, M., Pavenkov, O., Pavenkov, V. \& Vasilieva, E. (2015). The Language of Altruism: Corpus-based Conceptualisation of Social Category for Management Sociology. Asian Social Science. 11 (13), 289-297. http://dx.doi.org/10.5539/ass.v11n13p289

Rubtcova, M., Pavenkov, O., Pavenkov, V., Martianova, N. \& Martyanov, D. (2015). Deprofessionalisation as a Performance Management Dysfunction: The Case of Inclusive Education Teachers in Russia. Asian Social Science. 11(18), 339-349. DOI:10.5539/ass.v11n18p339

Rubtcova, M. V. (2015a). How 'Cognitive Linguistics' Can Help/Improve the Pragmatic Explanations of 'Altruism' in Russian. Cognitive Linguistics: Cognition, Language, Gesture eJournal, 7(10). http://dx.doi.org/10.2139/ssrn.2571947

Rubtcova, M.V. (2015b). Using Corpus Linguistics to Improve the Measurement of Advertising Effectiveness. Russian scientific-practical conference "Advertising and PR in the system of mass communication: psychological aspects of functioning". University of Cinema and Television. St. Petersburg. Russia. Managerial Marketing eJournal. 7(16). Retrieved from: http://ssrn.com/abstract $=2583473$

Rubtcova, M.V. (2015c). Corpus Linguistics in Sociological Research. Philosophy of Science eJournal. 8 (11). Retrieved from: http://ssrn. com/abstract $=2577167$

Rubtcova, M.V., Martianova, N. \& Pavenkov, O.V. (2015). Robert K. Merton's and Pitirim A. Sorokin's Concept 'Altruism': Conceptualisation and Operationalization for Sociological Research. Philosophy of Language eJournal. 8(8). Retrieved from: http://ssrn.com/abstract=2575098

Rubtsova, M. V. (2007). Manageability: sociological theoretical analysis of notions. Sotsiologicheskie Issledovaniya, (12), 32-38.

Rubtsova, M.V. (2009). Controllability and Power: Correlation of Notions in Sociology of Administration. Sociology of Power, (1), 57-59.

Rubtsova, M. V. (2011). Governmentability In interactions of subjects. Traditional and new practices. Sotsiologicheskie Issledovaniya, 
(2), 46-53.

Russian National Corpus (2015). Retrieved from: http://www.ruscorpora.ru

Sanina A. \& Rubtsova M. (2012). National Identity as a Factor of Control of Modern Society. The Journal of Sociology and Social Anthropology [Zhurnal Sociologii i Social"noj Antropologii]. XV. 3(62), 86-97.

Sanina, A. (2012). Competing for a citizen: "Visible" and "invisible" forms of state identity in Russia. Journal of Eurasian Studies, 3(2), 126-146.

Sartory, G. (1970). Concept Misformation in Comparative Politics. American Political Science Review, LXIV(4), 1033-1053

Seligman, A. (2000). The problem of trust. Princeton, NJ

Sztompka, P. (1999). Trust: A Sociological Theory. Cambridge: Cambridge University Press.

Vasilieva, E.A. (2015). The state service reflected by mass media of the Republic of Sakha (Yakutia): results of the empirical sociological research. Theory and practice of social development. 6. Retrieved from: http://www.teoria-practica.ru/vipusk-6-2015/

Vasilieva, E.A. 2011 The mythology of power: a sociological aspect. Science and Education. [Nauka i Obrazovanie] 3, 119-121.

Volchkova, L.T. \& Pavenkova, M.V. (2002). Sociology of management. Theoretical principles. Sotsiologicheskie issledovaniya. 3, 141144.

Watson, R. (2009). Constitutive Practices and Garfinkel's Notion of Trust: Revisited. Journal of Classical Sociology, 9 (4), 475-499.

Weber, M. (1997). The Theory of Social and Economic Organisation. Free Press

West D. \& Blackman D. (2015). Performance Management in the Australian Public Service: Where Has It Got To? Australian Journal of Public Administration, 1-9 http://dx.doi.org/10.1111/1467-8500.12130

Zornoza A., Orengo V. \& Peñarroja V. (2009). Relational capital in virtual teams: the role played by trust. Social Science Information, 48 (2). http://dx.doi.org/10.1177/0539018409102414

\section{Appendix 1}

The distribution of mention of the category "trust" on institutional and lexical contexts (the full scheme)

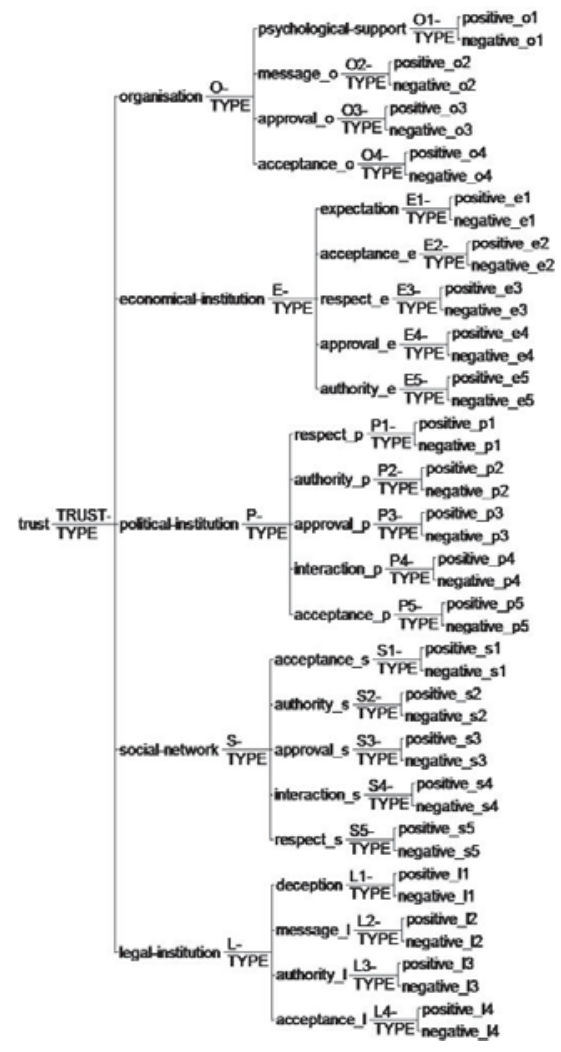

